Dansk Ultralyddiagnostisk Selskab

\section{Opfordring til indlæg i EjU}

Som tidligere opfordret vil DUDS $\mathrm{fx}$ via EJU meget gerne videreformidle, hvad der sker i dansk ultralyd af forsknings- og kvalitetssikringsprojekter, ph.d forsvar, disputatser, uddannelse etc. Som før nævnt er intet for stort eller småt. Indlæg kan sende til Peter Thielsen: n-formand@duds.dk

I dette nummer af EJU bringer vi et indlæg fra ultralydsgruppen under Syddansk Universitet.

\section{Ultrasonography research and innovation at University of Southern Denmark}

In the Region of Southern Denmark and at University of Southern Denmark, we have a long tradition of implementing ultrasonography in the daily clinical workflow. Besides the radiology departments many clinical departments are using ultrasound in the clinical work. Research and innovation within the field of ultrasonography have been integrated in the clinical practice at several levels some of which we would like to highlight here:

Within the field of abdominal radiology Professor Søren Rafaelsen and his group has published several articles in the area of testicular disease, colorectal cancers and liver disease. Associate Professor Ole Graumann and his group has published several articles within the field of uroradiology especially complexed renal cysts and renal cancer.

Professor Christian Godballe has published several articles within the field of Oto-RhinoLaryngology. Especially the upcoming project with contrast enhanced ultrasound (CEUS) for localizing pathological parathyroid glands in patients with primary hyperparathyroidism is very interesting.

Within the field of respiratory medicine Associate Professor Christian B. Laursen and his group has published several articles within the field of thoracic ultrasound (TUS). The group is part of an international collaboration developing evidence-based tools for training and competency assessment in TUS. This work is currently being implemented as part of a new European Respiratory Society thoracic ultrasound training programme.

Virtual reality (VR) and simulators have significant potential for improving blended learning and could potentially save face-to-

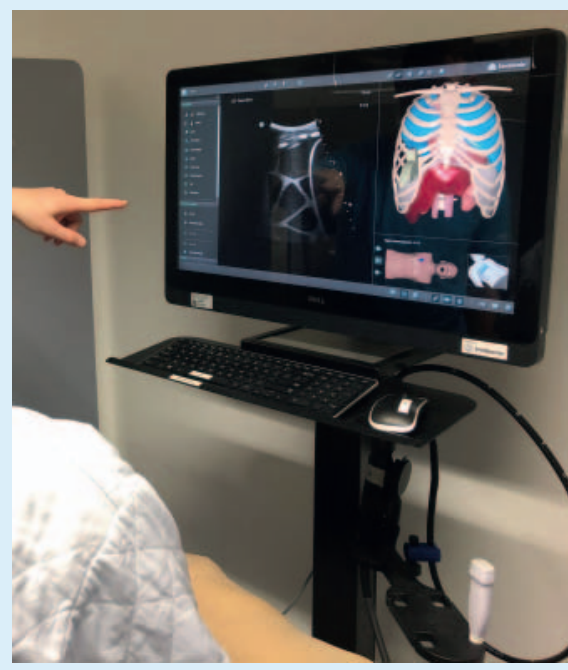

face teaching time and therefore resources. Groups within the Research and Innovation Unit of Radiology and the Regional Simulation Centre are working intensively to assess such blended learning tools within ultrasound education.

Ole Graumann, MD, PhD, Associate Professor

Christian B. Laursen, MD, PhD, Associate Professor 